Вавілова Надія, кандидат історичних наук, Національний університет оборони України імені Івана Черняховського, ORCID ID 0000-0002-0939-7820 DOI: $10.33099 / 2617-1775 / 2021-01 / 18-23$

\title{
ПОЛІТИКА ВІЙСЬКОВОЇ ОСВІТИ: ДОСВІД США ДЛЯ УКРАЇНИ
}

Досліджено питання досвіду регулювання та регламентації розвитку військової освіти у Сполучених Штатах Америки, визначено основні напрямки, проаналізовано зміст і структуру основного документу політики, ще встановлює головні пріоритети та регламентує шляхи $і$ способи досягнення визначених иілей військової освіти у США. Визначені перспективи розроблення політики військової освіти в Україні з урахуванням досвіду США у иіий сфері.

Ключові слова: військова освіта, США, політика, доктрина, концепція, НАТО, політика військової освіти, професійна військова освіта.

Постановка проблеми. Основною тенденцією розвитку системи військової освіти у країнах-членах НАТО є іiі професіоналізація 3 метою підвищення ефективності підготовки офіцерів та військових фахівців. Це обумовлено швидкими змінами оперативного середовища, зростанням актуальності його прогнозування для своєчасного реагування держави на майбутні виклики та загрози. Водночас зміни, які відбуваються, повинні враховуватися у системі військової освіти для визначення кваліфікаційних вимог до підготовки офіцерів та військових фахівців шляхом його організації і контролю. Існує слушна думка, що “саме організаційна культура, орієнтована на результат, більше відповідає умовам держав 3 демократичним устроєм, оскільки суспільство і платники податків очікують, що завдяки коштам, витраченим на безпеку та оборону, буде досягнутий очікуваний рівень захисту і безпеки. 3 другого боку, саме така культура забезпечує швидке реагування на зміни середовища безпеки" [3, с. 35]. Культура, про яку йдеться, охоплює і такий важливий напрямок, як правова культура. Проте на сьогодні вітчизняне правове поле ще слабко реагує на реальні потреби нормативно-правового регулювання процесів розвитку системи військової освіти, не враховуючи провідних тенденцій, які існують у зарубіжному досвіді, що є стримуючим фактором проведення швидких та якісних реформ у Збройних Силах України.

Метою статі є визначення перспектив розроблення політики військової освіти в Україні з урахуванням досвіду США у цій сфері.

Методи дослідження. У статті використано систему загальнонаукових і спеціальних методів теоретичного та емпіричного дослідження (систематизація та узагальнення, логічно-порівняльний методи, системний підхід, метод моделювання).

Виклад основного матеріалу. Кардинальні зміни структури системи військової освіти, які характерні для більшості країн-членів НАТО, мають на меті побудову сучасної моделі професійної військової освіти, що забезпечує підготовку офіцерів, здатних на практиці вирішувати складні завдання, 
пов’язані 3 усім комплексом проблем, що виникають в оперативному середовищі [1]. Ураховуючи що реформа системи національної безпеки i оборони України передбачає інтенсифікацію якісних змін у сфері підготовки офіцерських кадрів для Збройних Сил з урахуванням особливостей курсу держави на євроатлантичну інтеграцію, питання професіоналізації військової освіти в Україні є актуальним та потребує адекватного вирішення [2]. Одним 3 основних шляхів вирішення цього питання $\epsilon$ приведення вітчизняної нормативно-правової бази у відповідність стандартам НАТО, що передбачає не тільки гармонізацію вітчизняного законодавства з відповідними нормами, перш за все, європейського права, але й урахування досвіду провідних держав-членів НАТО у сфері регулювання та регламентації розвитку системи військової освіти - розроблення та імплементації таких нормативно-правових документів, як політики і доктрини.

Нормативно-правова база держав-членів НАТО у сфері розвитку військової освіти та підготовки офіцерів і військових фахівців в якості основних документів встановлює політики i доктрини, які отримують подальший розвиток у системі директивних документів. Основним документом, що встановлює головні пріоритети та регламентує шляхи і способи досягнення визначених цілей, є політика. Проте існують певні відмінності у структурі та змісті цього документу, який стандартизує процеси розвитку військової освіти в НАТО та державах-членах НАТО. Ці відмінності стосуються, перш за все, особливостей розвитку галузі воєнної науки. На здійснення освітньої діяльності у межах цієї галузі орієнтується США, розробляючи власну політику військової освіти [6]. Проте більшість європейських держав-членів НАТО позбавлені такої можливості (виключенням є лише Велика Британія), застосовуючи спільні стандарти розвитку військової освіти, викладені у відповідних нормативноправових документах НАТО [2; 3]. Україна сьогодні також здійснює освітню діяльність у межах галузі знань “Воєнні науки, національна безпека, безпека державного кордону", але прагне набути членства в НАТО, що встановлює певні вимоги та необхідність конструктивного перегляду основних принципів регулювання процесу розвитку вітчизняної військової освіти. Саме тому досвід США у сфері регулювання та регламентації розвитку військової освіти може сприяти проведенню в Україні реформування системи військової освіти за стандартами НАТО.

На сучасному етапі досвід США у питанні розроблення політики військової освіти важливий для України у декількох основних моментах. Поперше, ураховуючи відсутність у вітчизняному правовому полі подібного документу, важливо проаналізувати його структуру. По-друге, з'ясувати можливість адаптації тих чи інших розділів політики до змісту реформування системи військової освіти України.

У США процес нормативно-правового регулювання розвитку системи військової освіти (BО) у межах політик триває вже понад 30 років. За цей час суттєво змінилась форма та зміст документу, сфера його використання. 3 загальних проблем і напрямів розвитку системи ВО, які були викладені у перших документах, пріоритети поступово змінились на розроблення та 
деталізацію у рамках окремих політик, які стосуються питань професійної військової освіти (ПВО) різних категорій військовослужбовців та військових фахівців [4; 5; 7]. Водночас політики постійно переглядаються, отримуючи нове наповнення і зберігаючи актуальність відповідно новим загрозам міжнародній та національній безпеці, а також ураховують тенденції та перспективи розвитку стратегічної і оперативної обстановки.

Структура політики ВО має унормований характер. Документ обов'язково передбачає чітке формулювання мети, зазначення зв'язку 3 попередніми нормативно-правовими документами у цій сфері, визначення основних суб'єктів, які можуть застосовувати цей документ, формулювання стратегічного бачення перспектив розвитку системи ВО у зв’язку 3 визначеними необхідними результатами, перелік основних понять, визначення спроможностей, перелік змін, які відбуваються у діючих нормативно-правових документах внаслідок введення в дію нового документу, терміни впровадження документу в дію.

До структурних елементів політик, які регулюють та регламентують діяльність за конкретними напрямами реалізації загальної політики ВО (ПВО тощо), можуть додаватись інші елементи, які мають конкретизувати ті чи інші питання, зважаючи на їх специфіку та особливості. Так, політика ПВО, у рамках загальної політики ВО, у своїй структурі, крім вже наведених елементів, як правило, містить огляд (зв'язок з операційним середовищем, узгодження освітнього процесу 3 перспективним баченням професійних якостей офіцера майбутнього, його лідерських якостей тощо); визначення зв'язку даної політики 3 іншими; формулювання освітнього середовища на всіх рівнях військової освіти тощо [4; 5].

Наведені приклади елементів структури політики в узагальненому вигляді можливо адаптувати до потреб реформування вітчизняної системи ПВО у наступному варіанті відповідної політики:

1. Огляд (описання основних принципів політики ПВО, встановлення цілей ПВО, вимог до методології, освітніх вимог до управління, огляду та оцінки результатів ПВО).

2. Нормативні вимоги (визначається сутність та зміст ПВО, загальні напрямі розвитку освітніх програм ПВО).

3. Перспективи кар'єрного зростання (роль ПВО у просуванні по службі).

4. Результати (описання знань, вмінь та навичок, які надаються програмами ПВО).

5. Лідерські якості (визначення ролі i місця ПВО у формуванні в службових і посадових осіб лідерських якостей).

6. Освітне середовище (характеристика напрямів індивідуального розвитку особи на основі процесу безперервного навчання).

7. Підходи (визначення методології розробки освітніх програм для забезпечення потреб ПВО; управління системою ПВО тощо).

8. Оцінювання (підгрунтя оцінки ефективності ПВО).

9. Слухачі (визначення категорій слухачів ПВО).

10. Форми навчання. 
11. Перегляд політики (порядок і терміни внесення змін).

Безумовно, наведені елементи структури політики можуть і мають доповнюватись, відображаючи особливості розвитку системи ПВО в Україні, але процес адаптації документів подібного виду, які активно використовуються у державах-членах НАТО, створюють умови не тільки для чіткого формулювання цілей і завдань реформи військової освіти, але й визначення, управління $\mathrm{i}$ корегування основних напрямів iї розвитку на шляху євроатлантичної інтеграції держави.

Висновки та перспективи подалыших наукових розвідок. Завдання щодо розвитку військової освіти потребує не тільки перегляду концептуальних засад підготовки офіцерів тактичного, оперативного та стратегічного рівнів на основі імплементації ключових елементів відповідних концепцій країн-членів НАТО 3 урахуванням переоріснтації системи професійної підготовки офіцерських кадрів в Україні на спеціалізацію, інтенсивність та короткостроковість навчального процесу. Розвиток системи військової освіти у контексті реформування та будівництва Збройних Сил є невід'ємним від процесу законодавчого і нормативно-правового забезпечення. Досвід провідних держав-членів НАТО, зокрема США, свідчить про необхідність розроблення та імплементації у межах вітчизняного законодавчого поля таких нормативних документів, як політика. Це є важливим завданням, вирішення якого потребує здійснення подальших досліджень, перш за все, визначення співвідношення політики і концепції, їх сумісності та можливостей регулювати зазначену сферу.

\section{ЛІТЕРАТУРА}

1. Вітер Д. Професіоналізація військової освіти в Україні: головні напрямки, зміст та перспективи / Д. Вітер, О. Мітягін // Військова освіта. - 2020. - № 1(41). - С. 81-90.

2. Вітер Д. Стратегічні пріоритети підвищення боєздатності Збройних Сил України в контексті професіоналізації військової освіти: політики і процедури / Д. Вітер, О. Мітягін // 3б. наук. пр. ЦВСД. - 2020. - №1(68). - С. 133-137.

3. Пунда Ю. Освіта - головна інвестиція в розвиток людського капіталу сектору безпеки і оборони України / Ю. Пунда // Наука і оборона. - 2018. - № 1. - С. 34-40.

4. CJCSI 1805.01B 15 May 2015, "Enlisted Professional Military Education Policy”, Joint Staff, Washington, D.C. 20318. - URL: https://www.mil.gov.

5. CJCSI 1800.01F, Officer Joint Professional Military Education Policy, Instruction, Chairman of the Joint Chiefs of Staff, 1 December 2018. - URL: https://www.mil.gov.

6. Johnson-Freese J. The Reform of Military Education: Twenty-Five Years Later / Joan Johnson-Freese // Orbis. A Journal of World Affairs. - Vol. 56. - № 1. - 2012. - P. 135-153.

7. United States. Chairman of the Joint Chiefs of Staff. Officer Professional Military Education Policy (OPMEP). 1 December 2000. Washington, DC: JCS, 2000. "CJCSI 1800.01A". URL: https://www.jcs.mil.

\section{REFERENCES}

1. Viter D. Profesionalizatsiya viys'kovoyi osvity v Ukrayini: holovni napryamky, zmist ta perspektyvy / D. Viter, O. Mityahin // Viys'kova osvita. - 2020. - № 1(41). - S. 81-90.

2. Viter D. Stratehichni priorytety pidvyshchennya boyezdatnosti Zbroynykh Syl Ukrayiny v konteksti profesionalizatsiyi viys'kovoyi osvity: polityky i protsedury / D. Viter, O. Mityahin // Zb. nauk. pr. TSVSD. - 2020. - №1(68). - S. 133-137. 
3. Punda YU. Osvita - holovna investytsiya v rozvytok lyuds'koho kapitalu sektoru bezpeky i oborony Ukrayiny / YU. Punda // Nauka i oborona. - 2018. - № 1. - S. 34-40.

4. CJCSI 1805.01B 15 May 2015, "Enlisted Professional Military Education Policy”, Joint Staff, Washington, D.C. 20318. - URL: https://www.mil.gov.

5. CJCSI 1800.01F, Officer Joint Professional Military Education Policy, Instruction, Chairman of the Joint Chiefs of Staff, 1 December 2018. - URL: https://www.mil.gov.

6. Johnson-Freese J. The Reform of Military Education: Twenty-Five Years Later / Joan Johnson-Freese // Orbis. A Journal of World Affairs. - Vol. 56. - № 1. - 2012. - P. 135-153.

7. United States. Chairman of the Joint Chiefs of Staff. Officer Professional Military Education Policy (OPMEP). 1 December 2000. Washington, DC: JCS, 2000. "CJCSI 1800.01A". URL: https://www.jcs.mil.

\title{
РЕЗЮМЕ
}

\author{
Вавилова Надежда, \\ кандидат исторических наук \\ ведущий научный сотрудник \\ Национальный университет оборони \\ Украины имени Ивана Черняховского
}

\section{Политика военного образования: опыт США для Украины}

Исследован вопрос опьта регулирования и регламентаџии развития военного образования в Соединенных Штатах Америки, определень основные направления, проанализировано содержание и структуру основного документа политики, который устанавливает приоритеты и регламентирует пути и способы достижения поставленных целей военного образования в США. Определены перспективы разработки политики военного образования в Украине с учетом опыта США в этой сфере.

Ключевые слова: военное образование, США, политика, доктрина, концепџия, НАТО, политика военного образования, профессиональное военное образование.

\section{SUMMARY}

Vavilova Nadya,

$\mathrm{PhD}$ (History), Lead researcher National Defense University of Ukraine named after Ivan Cherniakhovskyi

\section{Military education policy: of USA for Ukraine}

Introduction. The main trend in the development of the military education system in NATO member states is its professionalization in order to increase the effectiveness of the training of officers and military specialists. This is due to rapid changes in the operational environment, the growing relevance of its forecasting for the timely response of the state to future challenges and threats.

Purpose. Determining the prospects for the development of military education policy in Ukraine, taking into account the US experience in this area.

Methods. The system of general scientific and special methods of theoretical and empirical research (analysis of scientific literature, systematization and generalization of materials, logic and comparative, content analysis) was used in order to realize the article purpose.

Results. The article examines the experience of regulating and regulating the development of military education in the United States, identifies the main directions, analyzes the content and structure of the main policy document, which sets the main priorities and ways and means to achieve certain goals of military education in the United States. Prospects for the development of military education policy in Ukraine are identified, taking into account the US experience in this area. 
Originality. US experience in regulating military education development can help reform Ukraine's military education system in line with NATO standards

Conclusion. The experience of leading NATO member states, in particular the United States, shows the need to develop and implement within the domestic legal field such normative documents as policy. This is an important task, the solution of which requires further research, first of all, to determine the relationship between policy and concept, their compatibility and the ability to regulate this area.

Key words: concept, doctrine, military education, military education policy, USA, NATO, policy, professional military education. 